\title{
"Tasting" fructose with pancreatic beta-cells: modulation of insulin release by sweet taste receptor signaling and its role in metabolic diseases
}

\author{
George A Kyriazis ${ }^{*}$, Kathleen R Mosure, Mangala M Soundarapandian, Richard E Pratley ${ }^{1,2}$, Björn Tyrberg \\ From Metabolism, diet and disease \\ Washington, DC, USA. 29-31 May 2012
}

\section{Background}

Although glucose is indispensable for the stimulation of insulin release, numerous other insulin secretagogues have been identified. For instance, the dietary monosaccharide fructose potentiates insulin secretion in vitro, but the mechanism and physiological significance remains unclear. The T1R2-T1R3 heterodimer of G protein-coupled receptors mediates sweet sensing in the tongue and ablation of either subunit obliterates sweet taste. We hypothesized that the effects of fructose on insulin release may be mediated by sweet taste receptors (TRs) on beta-cells.

\section{Materials and methods}

Mice with the homozygous deletion for the T1R2, T1R3, or TRPM5 gene (Dr. Zuker, Columbia University) were bred and genotyped in-house. In vitro static insulin release (ELISA, Mercodia) was assessed using cultured human and mouse islets incubated in custom-made wells with various treatments. Fura-2 based calcium imaging was performed using MIN6 cells or dispersed mouse beta-cells. Phospholipase C (PLC) activation was measured using Total Internal Reflection (TIRF) Microscopy in transfected MIN6 cells with a $\mathrm{PH}_{\mathrm{PLC} \delta 1}$-GFP construct. In vivo experiments were performed with 8-10 week old catheterized conscious male mice on regular chow after 5-hour fasting.
'Diabetes \& Obesity Research Center, Sanford-Burnham Medical Research institute, Orlando, FL 32827, USA

Full list of author information is available at the end of the article

\section{Results}

Human and mouse islets express sweet TRs. Fructose $(10.0 \mathrm{mM})$ rapidly activated PLC and increased intracellular calcium $\left(\mathrm{Ca}^{2+}{ }_{\mathrm{i}}\right)$ and insulin release at $8.3 \mathrm{mM}$ glucose in wild type (WT) islets and MIN6 cells, but these effects were absent in T1R2 knockout $\left(\mathrm{T} 1 \mathrm{R} 2^{-/}\right)$islets. Similar to mouse islets, fructose stimulated insulin release in human islets and these effects were blocked by lactisole, a human-specific inhibitor of T1R3. In vivo, an intravenous bolus of fructose $(1.0 \mathrm{~g} / \mathrm{kg})$ rapidly increased plasma insulin in WT, but not in T1R2 $2^{-/-}$mice. Glucose-stimulated insulin release (GSIS) in WT mice was potentiated by low physiological concentrations of fructose $(3.0 \mathrm{mM}$ in vitro; $0.3 \mathrm{~g} / \mathrm{kg}$ in vivo), but these effects were absent in $\mathrm{T} 1 \mathrm{R} 2^{-/-}$mice. The transient receptor potential channel M5 (TRPM5) mediates TR signaling in the tongue, contributing to cell membrane depolarization. Islets from TRPM5 knockout mice (TRPM5 ${ }^{-/-}$) failed to increase $\mathrm{Ca}^{2}$ ${ }^{+}$and insulin release in response to fructose. Finally, the expression of TRs is reduced in islets of diabetic mouse models $(\mathrm{db} / \mathrm{db})$ and is associated with impaired fructoseinduced insulin release.

\section{Conclusions}

Fructose is a natural ligand for functional sweet TRs expressed on mouse and human beta-cells. Pancreatic taste receptors sense circulating fructose and activate a distinct signaling pathway involving PLC, TRPM5 and $\mathrm{Ca}^{2+}$ influx that potentiates GSIS [1]. Our data together with previous reports showing that sweet TRs in the intestinal epithelium stimulate dietary glucose absorption and GLP-1 secretion, suggest a novel TR-dependent intestinopancreatic axis that participates in the regulation 
of postprandial insulin release by absorbed sugars. These data suggest a potential link between high-fructose consumption and the development of adverse metabolic effects. Interestingly, beta-cell TR expression and function is reduced in diabetic mouse phenotypes, also suggesting that impaired TR signaling may play a role in the pathogenesis of metabolic diseases.

\section{Author details}

'Diabetes \& Obesity Research Center, Sanford-Burnham Medical Research institute, Orlando, FL 32827, USA. ${ }^{2}$ Translational Research Institute for

Metabolism and Diabetes, Florida Hospital, Orlando, FL 32804, USA.

Published: 1 June 2012

\section{Reference}

1. Kyriazis GA, Soundarapandian MM, Tyrberg B: Sweet taste receptor signaling in $\beta$-cells mediates fructose-induced potentiation of glucosestimulated insulin secretion. Proc Natl Acad Sci USA 2012, 109:E524-32.

doi:10.1186/1753-6561-6-S3-P29

Cite this article as: Kyriazis et al:: "Tasting" fructose with pancreatic beta-cells: modulation of insulin release by sweet taste receptor signaling and its role in metabolic diseases. BMC Proceedings 20126 (Suppl 3):P29.

\section{Submit your next manuscript to BioMed Central} and take full advantage of:

- Convenient online submission

- Thorough peer review

- No space constraints or color figure charges

- Immediate publication on acceptance

- Inclusion in PubMed, CAS, Scopus and Google Scholar

- Research which is freely available for redistribution

Submit your manuscript at www.biomedcentral.com/submit 